J. Product. \& Dev., 16(2):201 - 222(2011)

\title{
GENETIC COMPONENTS OF SOME TRAITS IN EGGPLANT THROUGH DIALLEL ANALYSIS
}

\section{A. A. Gad; E.A. El-Ghamriny; H.E.M. Ismail and H.G. Zyada}

Hort. Department, Faculty of Agriculture, Zagazig University, Zagazig, Egypt.

\begin{abstract}
:
Five parents of eggplant were crossed in a diallel cross system; i.e., SBI-1.1 $\left(P_{1}\right), S B I-3.3\left(P_{2}\right), S B I-10.13\left(P_{3}\right), S B I-11.14$ $\left(P_{4}\right)$, and VS.1.13.19.1 Spain $\left(P_{5}\right)$, at El-Khattara Experimental Farm, Faculty of Agriculture, Zagazig University in 2005-2006 and evaluated in 2008 to study genetic components for some eggplant traits; i.e., plant height, branch number /plant, early fruit number, fruit weight / fruit in early yield, early yield / plant, total fruit number, fruit weight / fruit in total yield and total yield / plant.

The results reflected insignificant $t^{2}$ for all the studied traits, except early yield/plant which $t^{2}$ was significant. By inspection, $t^{2}$ was found insignificant after removing $P_{4}$. For all the studied traits, the estimates of $D, H_{1}$ and $H_{2}$ were significant for all these traits.

Asymmetrical gene distribution was observed, except total yield which had symmetrical gene distribution (0.25). For total yield, complete dominance was found to control this trait, and the dominance is isodirectional.
\end{abstract}

Key words: Genetic parameters \& components, heritability, narrow sense, diallel cross, eggplant, brinjal.

\section{INTRODUCTION}

Eggplant (Solanum melongena L.) occupy a position of considerable value because of its importance in the agricultural economy. The importance of eggplant as a vegetable in human diet needs no emphasis. Edible fruits of eggplant are consumed by many ways. 
Genetically studies; i.e., estimation of genetic parameters, and estimates of gca and sca are valuable for plant breeder, when planning a breeding program.

High heritability values were recorded for plant height and branch number per plant by Mehrotra and Dixit (1973), Borikar et al. (1981), Kalda et al. (1988) and Vadivel and Bapu (1989), for fruit number per plant by Hiremath and Gururaja (1974), Dharme Gowda et al.(1979), Salehuzzaman and Alam (1983), Kalda et al. (1988), Damnjanovic et al. (2002) and Mahaveer et al. (2004) and for average fruit weight and fruit yield per plant by Gill et al. (1976), Chung et al. (2003) and Omkar and Kumar (2005). In addition high heritability accompanied by high estimates of genetic advance (Mehrotra and Dixit, 1973; Bhutani et al., 1977; and Kalda et al., 1988) Chaudhary (1999) found both combining and component analysis showed presence of additive and non-additive gene effects with preponderance of latter. The mean degree of dominance indicated over- dominance for all traits, except fruit weight. Dominant and recessive alleles were symmetrically distributed among the parents for yield / plant and fruit weight, while were not symmetrical in the parents as indicated by the ratio $\mathrm{H}$ ${ }_{2} / 4 \mathrm{H}_{1}$, which was lower than 0.25 for fruit weight trait (Damnjanovic et al., 2002).

Therefore, present study on eggplant aimed to get information about the inheritance, genetic parameters for some important traits in eggplant using diallel cross system.

\section{MATERIALS AND METHODS}

Present study was carried out during four early summer growing seasons of 2005; 2006; 2007, and 2008, at El-Khattara Experimental Farm, Faculty of Agriculture, Zagazig University, Egypt.

This work was initiated to study the performance of some eggplant genotypes through $5 \times 5$ diallel cross system without reciprocals. The five eggplant cultivars used were; SBI-1.1 (P1), SBI-3.3 (P2), SBI-10.13 (P3), SBI-11.14 (P4), and VS.1.13.19.1 Spain (P5). The cultivars growth habit are presented in Table 1 . The 10 hybrids with 5 parents were planted in a completely randomized block design with 4 replications. Hand pollination was done to produce F1 seeds during 2005 and 2006. The entries in each replication consisted of 22 plants, planted at a spacing of $50 \times 100 \mathrm{~cm}$. The observations were recorded for plant height, branch number / plant, early yield / plant and its components, and total yield / plant and its components. 
Table 1. Plant height, branch number / plant, fruit shape, fruit colour and source of eggplant cultivars

\begin{tabular}{|c|c|c|c|c|c|}
\hline Cultivars & $\begin{array}{c}\text { Plant } \\
\text { height } \\
{[\mathrm{cm}]} \\
\end{array}$ & $\begin{array}{c}\text { Branch } \\
\text { number/ } \\
\text { plant }\end{array}$ & $\begin{array}{l}\text { Fruit } \\
\text { shape }\end{array}$ & $\begin{array}{l}\text { Fruit } \\
\text { colour }\end{array}$ & Sources \\
\hline 1.SBI-1.1 $\left(P_{1}\right)$ & 84.5 & 10.0 & Oblong & White Pink & E.I. Metwally \\
\hline 2. SBI-3.3 $\left(\mathbf{P}_{2}\right)$ & 75.2 & 9.0 & Long & White & E.I. Metwally* \\
\hline 3. SBI-10.13 $\left(\mathbf{P}_{3}\right)$ & 91.3 & 11.0 & Oblong & Black & E.I. Metwally \\
\hline 4. SBI-11.14 $\left(P_{4}\right)$ & 59.1 & 8.0 & Oblong & White & E.I. Metwally* \\
\hline $\begin{array}{l}\text { 5. VS.1.13.19.1 } \\
\text { Spain }\left(P_{5}\right)\end{array}$ & 80.8 & 10.0 & Oblong & $\begin{array}{c}\text { White, Red, } \\
\text { Strips }\end{array}$ & A.A. $\mathrm{Gad}^{* *}$ \\
\hline
\end{tabular}

* Hort. Department, Faculty of Agriculture, Kafr El-Sheikh University, Egypt.

** Hort. Department, Faculty of Agriculture, Zagazig University, Egypt.

\section{Statistical analysis:}

Estimation of genetic parameters for all the suggested traits, using the Hayman's approach; followed the theory of diallel, which was developed by Jinks and Hayman (1953), Jinks (1954) and Hayman (1954 a \& $\mathrm{b}$ and 1957) using Mather and Jinks (1971) concept of D and H components of variation. The second degree statistical variance and covariance were used for preparing two-quarter graphics ( $\mathrm{Wr} / \mathrm{Vr}$ ).

\section{RESULTS}

Analysis of genetic components of diallel cross system $(5 \times 5)$ in eggplant was run, according to Jinks and Hayman (1953), Jinks (1954) and Hayman (1954 a, b, and 1957) using Mather and Jinks (1971) concept of D and $\mathrm{H}$ components of variations, for growth traits, early yield / plant, and total yield / plant. The distribution of dominant and recessive genes among the parents can be shown from the order of the array points along the regression line (Wr / Vr graph). These results will be presented under the following topics.

\section{Genetic components:}

\section{Growth traits}

Data presented in Table 2, showed insignificant $\mathrm{t}^{2}$ for both growth traits; i.e., plant height and branch number/plant. It indicates the uniformity of $\mathrm{Wr}, \mathrm{Vr}$ and the validity of assumptions made by Hayman (1954 a \& b). 
Table 2. Estimates of the genetic components of variations and genetic ratios in $5 \times 5$ diallel of eggplant growth traits

\begin{tabular}{ccc}
\hline Parameters & Plant height [cm] & Branch number/plant \\
\hline $\mathbf{t}^{\mathbf{2}}$ & $2.112^{\mathrm{NS}}$ & $5.818^{\mathrm{NS}}$ \\
$\mathbf{E}$ & $12.710^{* *} \pm 4.148$ & $0.550^{* *} \pm 0.145$ \\
$\mathbf{D}$ & $135.160^{* *} \pm 10.162$ & $1.200^{* *} \pm 0.354$ \\
$\mathbf{H}_{\mathbf{1}}$ & $423.288^{* *} \pm 27.442$ & $0.848^{\mathrm{NS}} \pm 0.956$ \\
$\mathbf{H}_{\mathbf{2}}$ & $336.568^{* *} \pm 24.891$ & $0.703^{\mathrm{NS}} \pm 0.867$ \\
$\mathbf{F}_{\mathbf{r}}$ & $211.240^{* *} \pm 25.383$ & $0.912^{* *} \pm 0.885$ \\
$\left(\mathbf{H}_{\mathbf{1}} / \mathbf{D}\right)^{\mathbf{1} / \mathbf{2}}$ & 1.770 & 0.841 \\
$\mathbf{H}_{\mathbf{2}} / \mathbf{4} \mathbf{H}_{\mathbf{1}}$ & 0.20 & 0.21 \\
$\mathbf{h}_{\mathbf{2}}$ & $586.133^{* *} \pm 16.805$ & $-0.151^{\mathrm{NS}} \pm 0.586$ \\
$\mathbf{r}$ & -0.925 & 0.082 \\
$\mathbf{h}^{\mathbf{2}}(\mathbf{n s})$ & 5.21 & 22.93 \\
\hline
\end{tabular}

$\mathrm{NS}, *$ and **: Insignificant, significant and highly significant at 5\% and1\% levels of probability, respectively.

The additive genetic component of variation (D) for both growth traits was highly significant, indicates the role of additive in the inheritance of both traits. The two dominant components $\left(\mathrm{H}_{1}\right.$ and $\left.\mathrm{H}_{2}\right)$ were highly significant for plant height and insignificant for branch number / plant, respectively, indicate the role of dominance in the inheritance of plant height, but not so in branch number / plant.

Values of Fr for both traits (Table 2), were positive, and asymmetrical gene distribution was also observed. Since the values of $\mathrm{H}_{2}$ / $4 \mathrm{H}_{1}$ were 0.20 for plant height and 0.21 for branch number/plant, both values did not reach maximum gene distribution (0.25).

Inheritance of plant height was over-dominance for plant height (its degree of dominance, $\left.\left[\left(\mathrm{H}_{1} / \mathrm{D}\right)^{1 / 2}>1\right]\right)$ and partial dominance for branch number / plant $\left[\left(\mathrm{H}_{1} / \mathrm{D}\right)^{1 / 2}<1\right]$. The dominance effect overall luci $\left(\mathrm{h}_{2}\right)$ was positive and highly significant for plant height and was negative and insignificant for branch number / plant.

The correlation (r) between $\mathrm{Wr}+\mathrm{Vr}$ and $\mathrm{Yr}_{\mathrm{i}}$ had negative value and the parent containing most dominant gene was $\mathrm{P}_{5}$ (VS.1.13.19.1 Spain), since it had the lowest value of $\mathrm{Wr}+\mathrm{Vr}$ for plant height. For branch number / plant $\mathrm{P}_{2}$ (SBI-3.3) had most increasing genes (Table 5). 
The heritability ( $h^{2}$ n.s.) was $5.21 \%$ for plant height and $22.93 \%$ for branch number / plant.

\section{Early yield traits}

Data presented in Table 3, showed insignificant $\mathrm{t}^{2}$ for early yield traits. It indicates the uniformity of $\mathrm{Wr}, \mathrm{Vr}$ and the validity of assumptions made by Hayman (1954 a and b). Except early yield / plant, which had highly significant value, indicates that $\mathrm{Wr}, \mathrm{Vr}$ were not uniform.

The additive genetic component of variation (D) for early fruit number and weight of fruit were highly significant, indicates the role of additive in the inheritance of both the traits. The two dominant components $\left(\mathrm{H}_{1}\right.$ and $\left.\mathrm{H}_{2}\right)$ were highly significant for both the traits, except $\mathrm{H}_{2}$ for early fruit weight/fruit which was insignificant, indicates the role of dominance in the inheritance of early fruit number, but not so in early fruit weight and early yield. Insignificant $h_{2}$ was observed for the above mentioned traits, but it was positive for early fruit number and negative for fruit weight/fruit, indicates dominant and recessive effects over all loci in both traits, respectively. dominance for early yield $\left[\left(\mathrm{H}_{1} / \mathrm{D}\right)^{1 / 2}<1\right]$. The dominance effect overall luci $\left(h_{2}\right)$ was positive and insignificant for early fruit number and early fruit weight / fruit.

The correlation (r) between $\mathrm{Wr}+\mathrm{Vr}$ and Yri for early fruit number had positive value and the parent containing most dominant genes was P1 (SBI-1.1), since it had the lowest value of $\mathrm{Wr}+\mathrm{Vr}$ (Table 6).

For early fruit weight / fruit the correlation (r) had positive value and the parent containing most dominant gene was P5 (VS.1.13.19.1 Spain), since it had the lowest value of $\mathrm{Wr}+\mathrm{Vr}$ (Table 6). The heritability in narrow (h2ns) was $11.48 \%$ for early fruit number and $26.02 \%$ for early fruit weight / fruit.

For early yield /plant (Table 3), data indicated that the estimated genetic parameters were not dependable, since $\mathrm{t}^{2}$ value was significant and invalidity of the assumptions made by Hayman (1954 a and b), and its gene distributions reach 0.61 , more than its maximum values. So that, inspection was made by removing one parent from the analysis. Results in Table 3, after removing $\mathrm{P}_{4}$ (SBI-11.14), showed insignificant $\mathrm{t}^{2}$. It indicates the uniformity of $\mathrm{Wr}, \mathrm{Vr}$ and the validity of assumptions made by Hayman (1954 a \& b) for four parents inspects.

$\mathrm{D}, \mathrm{H} 1$ and $\mathrm{H} 2$ (Table 3), were highly significant, indicating that additive and dominance variances play a considerable roles in the 
Table 3. Estimates of the genetic components of variations and genetic ratios in $5 \times 5$ diallel for eggplant early yield/plant and its components

\begin{tabular}{|c|c|c|c|c|}
\hline \multirow[b]{2}{*}{ Parameters } & \multicolumn{4}{|c|}{ Early yield traits } \\
\hline & $\begin{array}{c}\text { Fruit } \\
\text { number/plant }\end{array}$ & $\begin{array}{c}\text { Fruit weight } \\
\text { (gm) }\end{array}$ & $\begin{array}{c}\text { Yield/plant } \\
\text { (kg) }\end{array}$ & $\begin{array}{l}\text { Yield after } \\
\text { removing } P_{4}\end{array}$ \\
\hline $\mathbf{t}^{2}$ & $6.405^{\mathrm{NS}}$ & $0.1^{-6 \mathrm{NS}}$ & $35.280^{\text {*3: }}$ & $0.400^{\mathrm{NS}}$ \\
\hline $\mathbf{E}$ & $\begin{array}{l}0.988^{\mathrm{NS}} \pm \\
2.177\end{array}$ & $\begin{array}{c}152.985^{* *} \\
81.412\end{array}$ & $\begin{array}{l}0.003^{\mathrm{NS}} \pm \\
0.009\end{array}$ & $\begin{array}{l}0.003^{* *} \pm \\
0.001\end{array}$ \\
\hline D & $54.742^{* *} \pm 5.333$ & $\begin{array}{l}223.859^{* *} \pm \\
199.418\end{array}$ & $\begin{array}{l}0.026^{* *} \pm \\
0.023\end{array}$ & $\begin{array}{l}0.036^{* *} \pm \\
0.002\end{array}$ \\
\hline $\mathbf{H}_{1}$ & $82.513^{* *} \pm 14.402$ & $\begin{array}{l}630.939^{* *} \pm \\
538.551\end{array}$ & $\begin{array}{l}0.016^{\mathrm{NS}} \pm \\
0.062^{-}\end{array}$ & $\begin{array}{l}0.084^{* *} \pm \\
0.002\end{array}$ \\
\hline $\mathbf{H}_{2}$ & $50.492^{* *} \pm 13.063$ & $\begin{array}{l}476.602^{\mathrm{NS}} \pm \\
488.472\end{array}$ & $\begin{array}{l}0.038^{\mathrm{NS}} \pm \\
0.057\end{array}$ & $\begin{array}{l}0.053^{* *} \pm \\
0.005\end{array}$ \\
\hline $\mathbf{F}_{\mathbf{r}}$ & $83.234^{* *} \pm 13.322$ & $\begin{array}{l}186.818^{\mathrm{NS}} \pm \\
498.146\end{array}$ & $\begin{array}{l}0.113^{* *} \pm \\
0.058\end{array}$ & $\begin{array}{l}0.062^{* *} \pm \\
0.005\end{array}$ \\
\hline$\left(H_{1} / D\right)^{1 / 2}$ & 1.228 & 1.679 & 0.775 & 1.519 \\
\hline $\mathrm{H}_{2} / 4 \mathrm{H}_{1}$ & 0.15 & 0.19 & 0.61 & 0.16 \\
\hline $\mathbf{h}_{2}$ & $2.084^{\mathrm{NS}} \pm 8.819$ & $\begin{array}{c}-78.054^{\mathrm{NS}} \pm \\
329.790\end{array}$ & $\begin{array}{l}0.010^{\mathrm{NS}} \pm \\
0.038\end{array}$ & $\begin{array}{l}0.040^{* *} \pm \\
0.003\end{array}$ \\
\hline $\mathbf{r}$ & 0.951 & 0.421 & -0.924 & 0.489 \\
\hline$h^{2}(n s)$ & 11.48 & 26.02 & 33.86 & 13.80 \\
\hline
\end{tabular}

NS, * and **: Insignificant, significant and highly significant at 5\% and1\% levels of probability, respectively.

inheritance of early yield trait.

Value of Fr for early yield / plant, after removing $\mathrm{P}_{4}$, was positive, and asymmetrical gene distribution was also observed, since the value of $\mathrm{H}_{2} / 4 \mathrm{H}_{1}$ was 0.16 . It indicates that most of the expression coming from dominant genes.

Inheritance of early yield / plant, after removing $\mathrm{P}_{4}$, was overdominance (its degree of dominance, $\left.\left[(\mathrm{H} 1 / \mathrm{D})^{1 / 2}>1\right]\right)$. The dominance effect overall luci $\left(\mathrm{h}_{2}\right)$ was positive and highly significant. The correlation (r) between $\mathrm{Wr}+\mathrm{Vr}$ and $\mathrm{Yr}_{\mathrm{i}}$ for early fruit number had positive value, and the 
parent containing most dominant genes was $\mathrm{P}_{1}$ (SBI-1.1), since it had the lowest value of $\mathrm{Wr}+\mathrm{Vr}$ f or early yield after removing $\mathrm{P}_{4}$.

The heritability $\left(h^{2}\right.$ n.s.) was $13.80 \%$ for early yield trait after removing $\mathrm{P}_{4}$.

\section{Total yield traits}

Data presented in Table 4, showed insignificant $\mathrm{t}^{2}$ for total fruit number /plant, fruit weight / fruit and total yield / plant. It indicates the uniformity of $\mathrm{Wr}, \mathrm{Vr}$ and the validity of assumptions made by Hayman (1954 a \& b).

The additive genetic component of variation (Table 4) for total yield and its components were highly significant, indicates the role of additive genetic variance in the inheritance of these traits. The two dominant components $\left(\mathrm{H}_{1}\right.$ and $\left.\mathrm{H}_{2}\right)$ were highly significant for all traits indicates also the role of dominance in the inheritance of yield traits.

Values of Fr for all traits (Table 4), were positive and highly significant for total fruit number and fruit weight/ fruit, and values of $h_{2}$ for both traits were positive, indicates the role of dominance in all the parents and crosses. Both traits also showed asymmetrical gene distribution, since the values of $\mathrm{H}_{2} / 4 \mathrm{H}_{1}$ were 0.16 for total fruit number and 0.15 for total fruit weight. Both traits showed over- dominance in their inheritance. Heritability $\left(h^{2}\right.$ n.s.) for fruit number and fruit weight were moderate.

The correlation $(r)$ between $\mathrm{Wr}+\mathrm{Vr}$ and $\mathrm{Yr}_{i}$ for fruit number had positive value and the parent containing most dominant genes was $\mathrm{P}_{1}$ (SBI1.1), since it had the lowest value of $\mathrm{Wr}+\operatorname{Vr}$ (Table 7).

For fruit weight / fruit, the correlation (r) was negative and the parent containing most dominant genes was $\mathrm{P}_{1}$ (SBI-1.1), since it had the lowest value of $\mathrm{Wr}+\mathrm{Vr}$ for fruit weight / fruit (Table 7).

For total yield/plant (Table 4), D, $\mathrm{H}_{1}$ and $\mathrm{H}_{2}$ were highly significant, indicating that additive and dominance variances play a considerable role in the inheritance of total yield / plant.

For total yield value, when rounded, will be equal zero, that is logic value for total yield, since it had equal gene distribution was observed $\left(\mathrm{H}_{2} / 4\right.$ 
Table 4. Estimates of the genetic components of variations and genetic ratios in $5 \times 5$ diallel for eggplant total yield/plant and its components

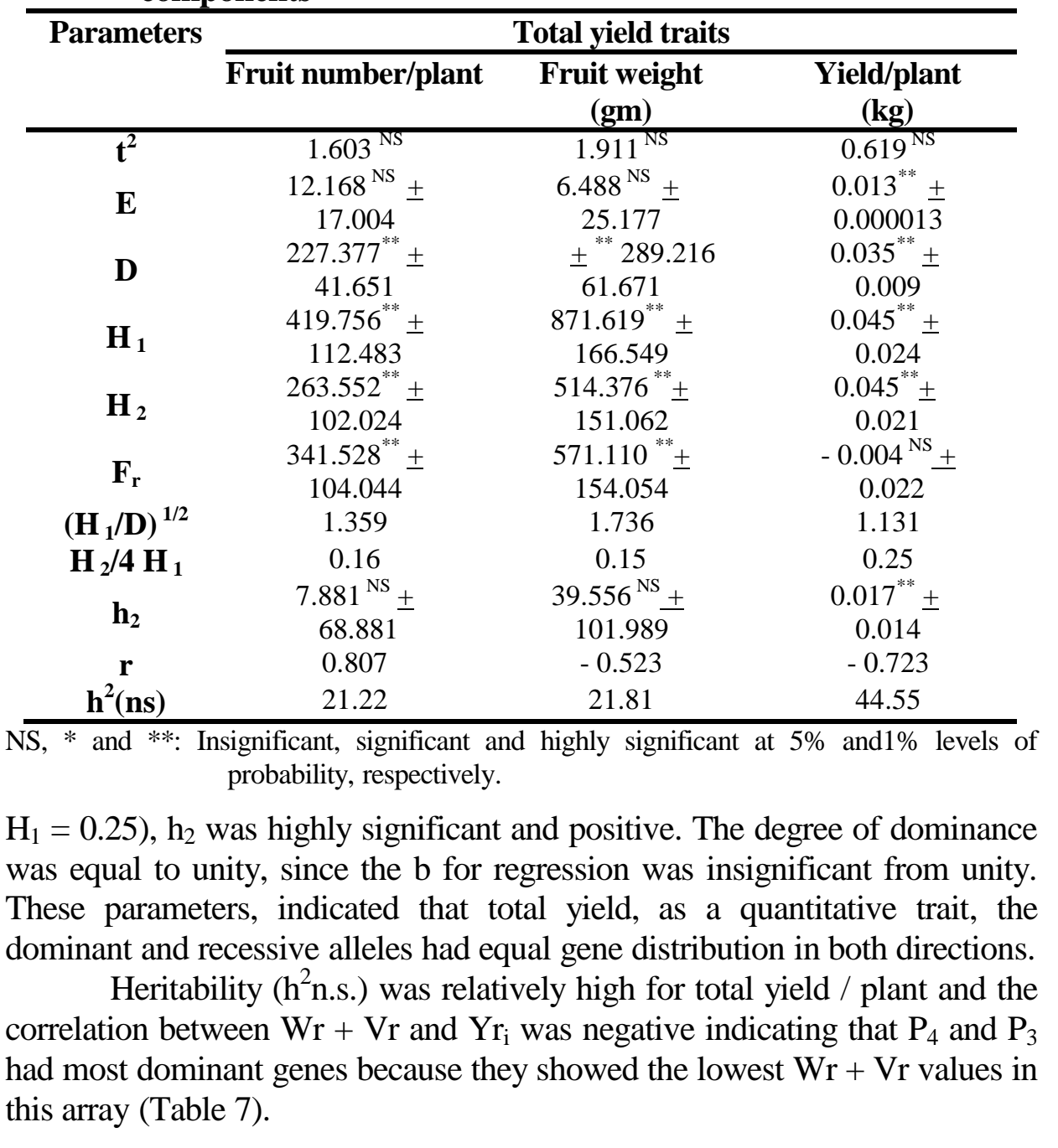

\section{Wr / Vr Graph:}

\section{Growth traits}

The relation of $\mathrm{Wr}$ with $\mathrm{Vr}$ (Table 5 and Figures $1 \& 2$ ) for plant height and branch number / plant, respectively, showed that their b (slope) were positive and insignificant for both traits. 
Table 5. Wr-Vr relationship of the studied eggplant parental genotypes for some plant growth traits

\begin{tabular}{|c|c|c|c|c|c|c|c|c|c|c|}
\hline \multirow[b]{2}{*}{ Array } & \multicolumn{5}{|c|}{ Plant height (cm) } & \multicolumn{5}{|c|}{ Branch number/plant } \\
\hline & $\mathbf{W r}$ & $\mathbf{V r}$ & $\begin{array}{l}\text { Wr - } \\
\text { Vr }\end{array}$ & $\begin{array}{c}\mathrm{Wr}+ \\
\mathrm{Vr}\end{array}$ & Yr & Wr & Vr & $\begin{array}{l}\text { Wr - } \\
\text { Vr }\end{array}$ & $\begin{array}{c}\mathbf{W r}+ \\
\mathbf{V r}\end{array}$ & Yr \\
\hline SBI-1.1 $\left(\mathbf{P}_{1}\right)$ & -29.40 & 49.50 & -78.90 & 20.10 & 84.50 & 0.97 & 0.67 & 0.30 & 1.64 & 10.00 \\
\hline SBI-3.3 $\left(\mathbf{P}_{2}\right)$ & 2.58 & 75.75 & -73.17 & 78.33 & 75.20 & -0.62 & 0.25 & -0.87 & -0.37 & 9.00 \\
\hline SBI-10.13 $\left(\mathbf{P}_{3}\right)$ & -31.35 & 25.93 & -57.28 & -5.42 & 91.25 & 0.85 & 0.75 & 0.10 & 1.60 & 11.00 \\
\hline SBI-11.14 $\left(\mathbf{P}_{4}\right)$ & 191.77 & 284.02 & -92.25 & 475.79 & 59.08 & 0.74 & 0.99 & -0.25 & 1.73 & 7.50 \\
\hline VS.1.13.19.1 Spain $\left(\mathbf{P}_{5}\right)$ & -47.04 & 36.94 & -83.98 & -10.10 & 80.83 & 0.47 & 0.41 & 0.06 & 0.88 & 10.00 \\
\hline$X$ & 17.31 & 94.43 & -77.12 & 111.74 & 78.17 & 0.48 & 0.61 & -0.13 & 1.10 & 9.50 \\
\hline
\end{tabular}

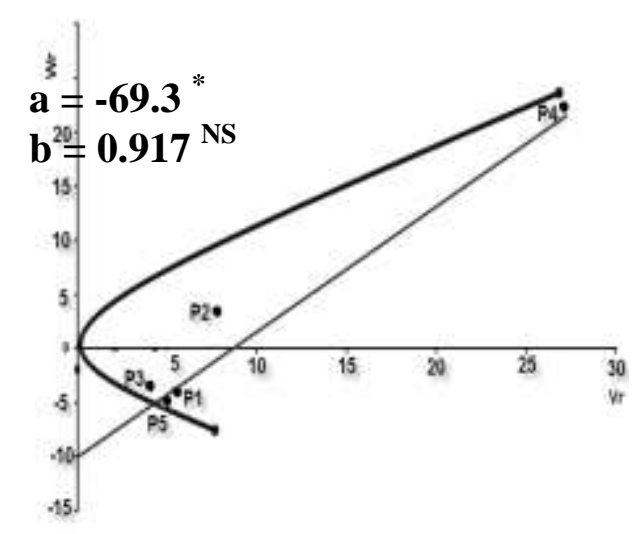

Figure 1. Wr/Vr graph for plant height

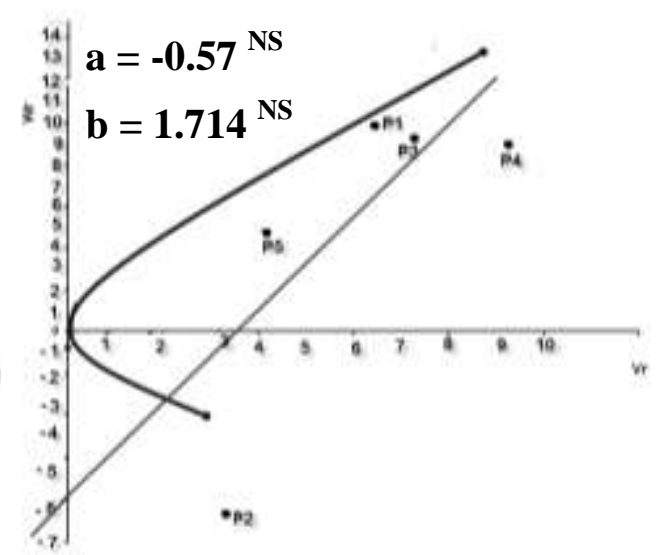

Figure 2.Wr/Vr graph for branch number/plant

For plant height (Figure1), the regression line intersect $\mathrm{Wr}$ below the origin and its "a" value was negative and significant from zero, indicating that the trait was under control of over-dominance. The parents that had most dominant genes were $\mathrm{P}_{5}, \mathrm{P}_{3}$ and $\mathrm{P}_{1}$ and that had most recessive genes was $\mathrm{P}_{4}$. 
For branch number / plant (Figure 2), intersection point was below the origin. However, its "a" value was negative and insignificant, indicating that the "a" value did not differ from zero point. So that, this trait was under control of complete dominance. The parent $\mathrm{P}_{2}$ had most dominant genes, while $\mathrm{P}_{3}$ and $\mathrm{P}_{1}$ parents had the most recessive genes.

\section{Early yield traits}

The relation of $\mathrm{Wr}$ with $\operatorname{Vr}$ (Table 6 and Figures 3, 4 and 5) for early yield traits showed that their $\mathrm{b}$ (slopes) were negative for individual fruit weight and early yield, but it was positive for early fruit number.

For early fruit number (Figure 3), the regression line intersect $\mathrm{Wr}$ below the origin, so that the trait under control of over dominance, this result was conformed by significant and negative "a" value. The parents that had most dominant genes were $\mathrm{P}_{2}, \mathrm{P}_{1}$ and $\mathrm{P}_{3}$; and that had most recessive genes was $\mathrm{P}_{4}$. For early fruit weight / fruit (Figure 4), intersection point was above the origin. Its "a" value was positive and insignificant, so that this value "a" did not differ from zero point. The parent $\mathrm{P}_{2}$ had most dominant genes, while the parents $\mathrm{P}_{3}$ and $\mathrm{P}_{4}$ had the most recessive genes.

For early yield / plant (Figure 5), convex b slope had insignificant negative value, and two out of the five parents fall outside the parabola. Such results conformed invalidity of the assumptions of diallel analysis derived from significant $\mathrm{t}^{2}$. By inspection, retrying and analysis of the diallel cross system by removing one parent to fulfill the uniformity of $\mathrm{Wr}, \mathrm{Vr}$ and the validity of the assumptions. By removing $\mathrm{P}_{4}$ (SBI-11.14) the rest parents were fall inside the parabola and fulfill and the validity of the model (Fig. 6).

$\mathrm{Wr} / \mathrm{Vr}$ graph (Figure 6), indicates positive insignificant $\mathrm{b}$ value, and the b slope intersect $\mathrm{Wr}$ below origin, since "a" was negative and significant from zero; this indicated that, the trait was under control of overdominance. It also showed that most of dominant and recessive genes were presented in $\mathrm{P}_{1}$ (SBI-1.1) and $\mathrm{P}_{5}$ (VS.1.13.19.1 Spain), respectively.

\section{Total yield traits}

The relation of $\mathrm{Wr}$ with $\operatorname{Vr}$ (Table 7 and Figures 7, 8 and 9) for total yield traits showed that their b's (slope) were positive and insignificant for total yield and its components. 
Table 6. Wr-Vr relationship for early yield traits of the studied eggplant parental genotypes

\begin{tabular}{|c|c|c|c|c|c|}
\hline \multirow[b]{2}{*}{ Array } & \multicolumn{5}{|c|}{ Early yield traits } \\
\hline & $\mathbf{W r}$ & $\mathbf{V r}$ & $\mathrm{Wr}-\mathrm{Vr}$ & $\mathrm{Wr}+\mathrm{Vr}$ & Yr \\
\hline \multicolumn{6}{|c|}{ Fruit number/plant } \\
\hline SBI-1.1 ( $\left.\mathbf{P}_{1}\right)$ & -12.000 & 4.420 & -16.420 & -7.580 & 5.010 \\
\hline $\operatorname{SBI-3.3}\left(\mathbf{P}_{2}\right)$ & -1.500 & 4.200 & -5.700 & 2.700 & 2.570 \\
\hline SBI-10.13 $\left(\mathbf{P}_{3}\right)$ & -6.750 & 4.600 & -11.350 & -2.150 & 2.100 \\
\hline SBI-11.14 $\left(\mathbf{P}_{4}\right)$ & 50.950 & 49.190 & 1.760 & 100.140 & 19.240 \\
\hline VS.1.13.19.1 Spain $\left(\mathbf{P}_{5}\right)$ & 3.100 & 8.080 & -4.980 & 11.180 & 1.560 \\
\hline $\bar{X}$ & 6.760 & 14.100 & -7.340 & 20.860 & 6.100 \\
\hline \multicolumn{6}{|c|}{ Fruit weight (gm) } \\
\hline SBI-1.1 ( $\left.\mathbf{P}_{1}\right)$ & 233.180 & 214.940 & 18.240 & 448.120 & 73.250 \\
\hline SBI- $3.3\left(\mathbf{P}_{2}\right)$ & 129.450 & 60.680 & 68.770 & 190.130 & 58.330 \\
\hline $\operatorname{SBI}-10.13\left(\mathbf{P}_{3}\right)$ & 294.700 & 384.950 & -90.250 & 679.650 & 79.200 \\
\hline SBI-11.14 $\left(\mathbf{P}_{4}\right)$ & -75.950 & 496.220 & -572.170 & 420.270 & 29.750 \\
\hline VS.1.13.19.1 Spain $\left(\mathbf{P}_{5}\right)$ & -102.270 & 137.140 & -239.410 & 34.870 & 52.600 \\
\hline$\overline{\bar{X}}$ & 95.820 & 258.790 & -162.960 & 354.610 & $\mathbf{5 8 . 6 3 0}$ \\
\hline \multicolumn{6}{|c|}{ Yield/plant (kg) } \\
\hline SBI-1.1 ( $\left.\mathbf{P}_{1}\right)$ & -0.001 & 0.005 & -0.006 & 0.004 & 0.367 \\
\hline SBI-3.3 $\left(\mathbf{P}_{2}\right)$ & 0.009 & 0.016 & -0.007 & 0.025 & 0.150 \\
\hline $\operatorname{SBI-10.13}\left(\mathbf{P}_{\mathbf{3}}\right)$ & -0.006 & 0.010 & -0.016 & 0.004 & 0.166 \\
\hline SBI-11.14 $\left(\mathbf{P}_{4}\right)$ & -0.017 & 0.011 & -0.028 & -0.006 & 0.572 \\
\hline VS.1.13.19.1 Spain $\left(\mathbf{P}_{5}\right)$ & -0.057 & 0.021 & -0.078 & -0.036 & 0.821 \\
\hline$\overline{\mathrm{X}}$ & -0.014 & 0.013 & -0.027 & -0.002 & 0.415 \\
\hline
\end{tabular}




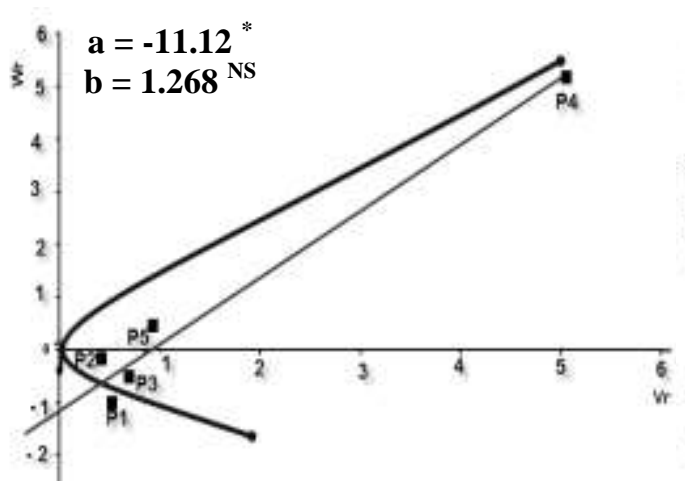

Figure 3. Wr/Vr graph for early fruit number/plant

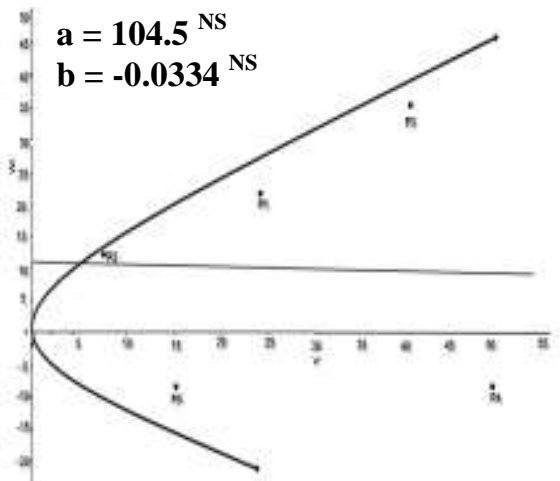

Figure 4. $\mathrm{Wr} / \mathrm{Vr}$ graph for early fruit weight/fruit (gm)

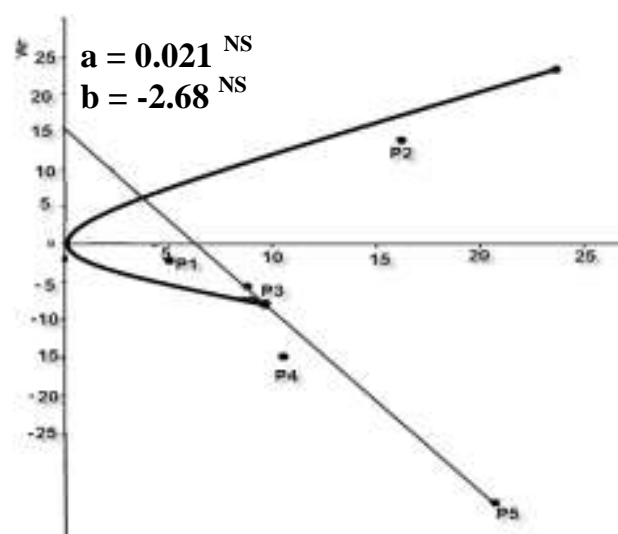

Figure 5. $\mathrm{Wr} / \mathrm{Vr}$ graph for early yield / plant $(\mathrm{kg})$

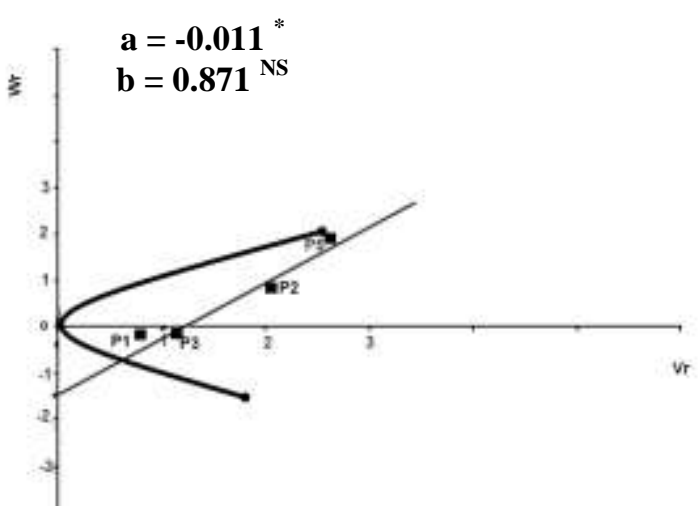

Figure 6. $\mathrm{Wr} / \mathrm{Vr}$ graph for early yield/plant after removing P4.

For total fruit number (Figure 7), the regression line intersect $\mathrm{Wr}$ below the origin and its "a" value was negative and significant, so that the trait was under the control of over-dominance. The parent that had most dominant genes was $\mathrm{P}_{3}$ and that had most recessive genes was $\mathrm{P}_{4}$.

For fruit weight /fruit (Figure 8), intersection point was below the origin, so that the trait was under the control of over dominance. The parent $\mathrm{P}_{2}$ had most dominant genes and that had the most recessive genes was $\mathrm{P}_{4}$. 
Table 7. Wr-Vr relationship for total yield traits of the studied eggplant parental genotypes

\begin{tabular}{|c|c|c|c|c|c|}
\hline \multirow[b]{2}{*}{ Array } & \multicolumn{5}{|c|}{ Total yield traits } \\
\hline & Wr & $\mathbf{V r}$ & Wr $-V \mathbf{r}$ & $W r+V r$ & Yr \\
\hline \multicolumn{6}{|c|}{ Fruit number/plant } \\
\hline SBI-1.1 ( $\left.\mathbf{P}_{1}\right)$ & -80.680 & 53.900 & -134.580 & -26.780 & 24.950 \\
\hline SBI- 3.3 ( $\left.\mathbf{P}_{2}\right)$ & 11.110 & 14.980 & -3.870 & 26.090 & 11.790 \\
\hline $\operatorname{SBI-10.13}\left(\mathbf{P}_{\mathbf{3}}\right)$ & - 24.100 & 39.940 & -64.040 & 15.840 & 15.350 \\
\hline SBI-11.14 $\left(\mathbf{P}_{4}\right)$ & 212.400 & 216.910 & -4.510 & 429.310 & 48.160 \\
\hline VS.1.13.19.1 Spain $\left(\mathbf{P}_{5}\right)$ & 34.970 & 92.780 & -57.810 & 127.750 & 11.180 \\
\hline$\overline{\mathrm{X}}$ & 30.740 & 83.700 & -52.960 & 114.440 & 22.290 \\
\hline \multicolumn{6}{|c|}{ Fruit weight (gm) } \\
\hline SBI-1.1 ( $\left.\mathbf{P}_{1}\right)$ & -154.640 & 116.430 & -271.070 & -38.210 & 38.800 \\
\hline SBI-3.3 $\left(\mathbf{P}_{2}\right)$ & -67.470 & 52.440 & -119.910 & -15.030 & 39.500 \\
\hline SBI-10.13 $\left(\mathbf{P}_{\mathbf{3}}\right)$ & -42.610 & 139.680 & -182.290 & 97.070 & 59.630 \\
\hline SBI-11.14 $\left(\mathbf{P}_{4}\right)$ & 245.170 & 326.270 & -81.100 & 571.440 & 20.550 \\
\hline VS.1.13.19.1 Spain $\left(\mathbf{P}_{5}\right)$ & 35.190 & 121.800 & -86.610 & 156.990 & 62.480 \\
\hline$\overline{\bar{X}}$ & 3.128 & 151.324 & -148.196 & 154.452 & 44.192 \\
\hline \multicolumn{6}{|c|}{ Yield/plant (kg) } \\
\hline SBI-1.1 $\left(\mathbf{P}_{1}\right)$ & 0.011 & 0.030 & -0.019 & 0.041 & 0.968 \\
\hline SBI-3.3 $\left(\mathbf{P}_{2}\right)$ & 0.038 & 0.033 & 0.005 & 0.071 & 0.466 \\
\hline $\operatorname{SBI-10.13}\left(\mathbf{P}_{\mathbf{3}}\right)$ & 0.010 & 0.014 & -0.004 & 0.024 & 0.915 \\
\hline SBI-11.14 $\left(\mathbf{P}_{4}\right)$ & 0.004 & 0.004 & -0.0001 & 0.005 & 0.990 \\
\hline VS.1.13.19.1 Spin $\left(\mathbf{P}_{5}\right)$ & 0.043 & 0.063 & -0.020 & 0.106 & 0.699 \\
\hline$\overline{\mathrm{X}}$ & 0.021 & 0.029 & -0.008 & 0.050 & 0.808 \\
\hline
\end{tabular}

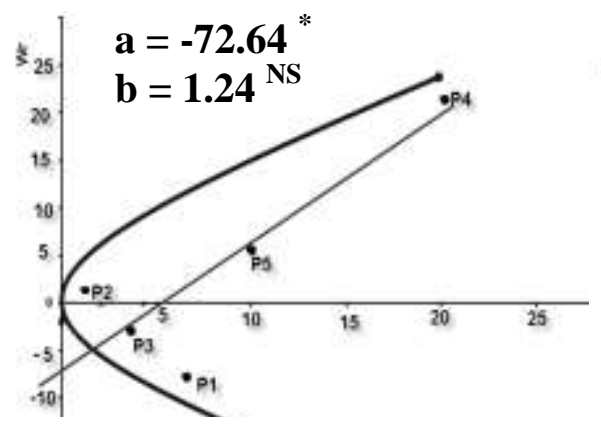

Figure7 : Wr/Vr graph for fruit number in total yield

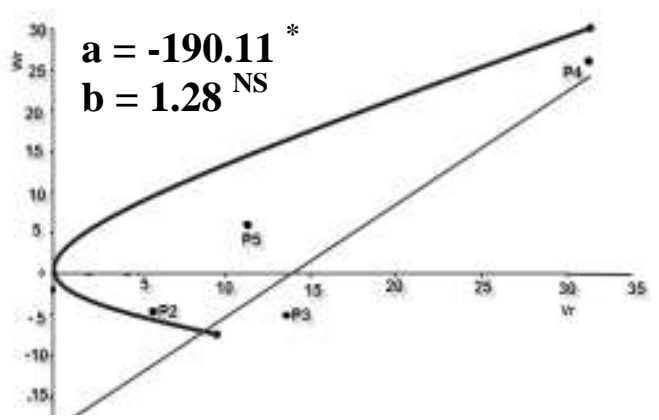

Figure 8. $\mathrm{Wr} / \mathrm{Vr}$ graph for fruit weight/fruit in total yield (gm) 


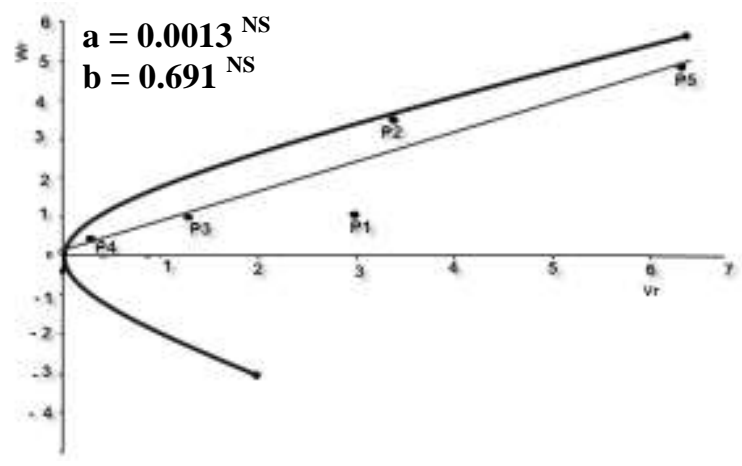

Figure9: $\mathrm{Wr} / \mathrm{Vr}$ graph for total yield/plant $(\mathrm{kg})$

For total yield / plant (Figure 9), intersection point was near to the origin and its "a" value was insignificant from zero, so that the trait under control of complete dominance. The parent that had most dominant genes was $\mathrm{P}_{4}$ and that had most recessive genes was $\mathrm{P}_{5}$.

\section{DISCUSSION}

From the analysis of $5 \times 5$ diallel crossing system in eggplant, and testing the hypothesis proposed by Hayman (1954 a and b), non significant $\mathrm{t}^{2}$ values for all the studied traits (Tables 2 and 3), except early fruit yield $\left(\mathrm{t}^{2}\right.$ was insignificant). For the former traits, these results supported the assumptions underlying this analysis. For the later trait (early fruit yield), by removing $\mathrm{P}_{4}$ and reanalysis by $4 \times 4$ diallel, $\mathrm{t}^{2}$ was found insignificant indicating the validity of hypothesis under this situation (Table 3, Col. 4). Similar results were reported by Peter and Singh (1974) and Gulam-ud-din et al. (1999).

\section{Growth traits}

The additive component (D) for plant height and branch number/ plant was highly significant. It was less than $\mathrm{H}_{1}$ and $\mathrm{H}_{2}$ for plant height and higher than $\mathrm{H}_{1}$ and $\mathrm{H}_{2}$ for branch number/plant, indicating the role of dominance and additive genetic components in the inheritance of both the traits, respectively. Moreover, plant height and branch number, according to the degree of dominance, were under over- dominance (1.77) and partial dominance (0.84), respectively. The value of the additive component of variance (D) was higher than $\mathrm{H}_{1}$ and $\mathrm{H}_{2}$, indicating that the main part of the 
genetic variance belonged to the additive gene effect. (Damnjanovic et al., 2002). Singh and Singh (1979) obtained the same result.

In accordance to the findings of Dharme Gowda (1977) and Iqubal et al. (1995) the analysis of variance of combining ability for plant height in the $F_{1}$ generation showed significant additive and non-additive gene effect, with prevailing influences additive effect (Damnjanovic et al., 2002). Nonadditive gene action was predominant in the $F_{1}$ for plant height, while additive gene action was important for number of branches per plant (Singh et al., 1979). Abd El-Hadi et al. (2004) reported that the calculated values of general combining ability $\left(\sigma_{\mathrm{g}}^{2}\right)$ and specific combining ability $\left(\sigma_{\mathrm{s}}^{2}\right)$ variances were translated to genetic variance components such as additive genetic variance including dominance $\left(\sigma_{\mathrm{D}}^{2}\right)$ and the results of plant height and branch number / plant.

For both traits, gene distribution among parents was asymmetrical and Fr was positive and highly significant. Therefore, most of the expression of both traits (plant height and branch number / plant) was coming from dominant alleles, irrespective whether they were increasing or decreasing. Besides, the ratio of $\sigma_{s}^{2} / \sigma_{g}^{2}$ was also greater than one for all the characters, thereby, indicating preponderance of non-additive variance for plant height and spread (Aswani and Khandelwal, 2005). These results are in close conformity with Bhutani et al. (1980) and Singh et al. (1991).

Heritability in narrow sense was low and moderate for plant height and branch number / plant, respectively. These results means that, both the traits were much affected by environments. Gill et al. (1976) found that high heritability for all studied characters except the number of branches per plant. In contrast, high heritability values were recorded for plant height and branches number per plant by Mehrotra and Dixit (1973), Borikar et al. (1981), Kalda et al. (1988) and Vadivel and Bapu (1989).

Selection in advanced selfing generation for high number could be effective, since it had highly significant value of $\mathrm{D}$ component and that could improve the yield of eggplant through increasing number of branches / plant. The estimates of components of variance for combining ability, genetic components of variance and average degree of dominance for plant height and plant spread (Ahmed et al., 2003). The results obtained that selection of parents to be included in hybridization program could also be judged on per se performance, besides, general combining ability effects. 
Similar associations between these two parameters was also observed by Bhutani et al. (1980) and Singh and Hazarika (1982). The estimates of variances showed high general combining ability (GCA) and specific combining ability (SCA) effects for plant height, indicating additive $\times$ additive gene action (Chezhian et al., 2000).

Branch number / plant in eggplant was considered one of the yield components (Singh et al., 2002). Concerning selection effect Bhutani et al. (1980) and Singh and Hazarika (1982) reported that the results obtained that selection of parents to be included in hybridization program could also be judged on per se performance, besides, general combining ability effects. Similar associations between these two parameters were also observed by Bhutani et al. (1980).

\section{Early yield traits}

The additive component (D) for early fruit number, weight of fruit and early yield was highly significant. It was less than $\mathrm{H}_{1}$ and $\mathrm{H}_{2}$ for weight of fruit and early yield after removing $\mathrm{P}_{4}$ (Table 3 , Col. 4), and higher than $\mathrm{H}_{2}$ for early fruit number and higher than $\mathrm{H}_{1}$ for early yield (Table 3, Col. 3), indicating the role of dominance and additive genetic components in the inheritance of these traits. Moreover, early yield traits, according to the degree of dominance, were under over-dominance (1.23, 1.68, and 1.52), except early yield/plant (Table 3, Col. 3) was partial dominance (0.78). Hani et al. (1977) observed non-additive effects pre-dominated for early yield.

For these traits, gene distribution among parents was asymmetrical and Fr was positive and highly significant, except weight of fruit which was insignificant. Therefore, most of the expressions of these traits (early yield and its components) were coming from dominant alleles, irrespective whether they were increasing or decreasing. Similar results on tomato early yield traits were also observed by Ismail (1997).

Heritability in narrow sense was low and moderate for early yield traits. These results means that, these traits were much affected by environments. The analysis of variance revealed that both gca and sca variances were significant for fruits / plant, fruit weight, and fruit yield. Variance due to sca alone was significant for fruit yield. This indicates the importance of both additive and non-additive gene effects for early yield traits (Padmanbham and Jagadish, 1996). Peter and Singh (1974) reported that both gca and sca variances were significant for early yield and fruit 
yield / plant. Both gca and sca effects were significant for early yield and fruit yield / plant (Peter and Singh, 1974), while both gca and sca variances were reported to be significant early yield and yield/ plant (Mital et al., 1976; and Vijay et al., 1978).

\section{Total yield traits}

The additive component (D) for total yield and its components was highly significant. It was less than $\mathrm{H}_{1}$ and $\mathrm{H}_{2}$ for all traits, indicating the role of dominance in the inheritance of yield traits. Moreover, total fruit number and fruit weight / fruit, according to the degree of dominance, were under overdominance (1.36 and 1.74) and complete dominance (1.13) for total yield / plant.

For both traits, gene distribution among parents was asymmetrical and Fr was positive and highly significant for total fruit number and fruit weight / fruit. Therefore, most of the expression of both traits was coming from dominant alleles, irrespective whether they were increased or decreased. For total yield, gene distribution among parents was symmetrical $(0.25)$, at equal gene distribution $=0.25$, and negative insignificant $\mathrm{Fr}$, indicating that dominance and recessiveness are equal in both directions. So that total yield as a quantitative character, it has fulfilled its assumptions. But, Damnjanovic et al. (2002) showed that, the value of Fr was negative in the expression of fruit number per plant, indicating the recessive alleles prevailed over the dominant ones.

Heritability in narrow sense was low and moderate for total yield traits. These results means that, these traits were much affective by environments. Baig and Patil (2002) revealed that gca and sca variances were highly significant for all the characters. Both gca and sca showed significant interaction with environments for all the traits. The significant gca $\times$ environment and sca $\times$ environment interaction indicated that the estimates of both additive and non-additive gene effects are prone to change with the environment. Similar results were also reported by Warade (1986) and Barbind (1990). The ratio of additive variance to total genotypic variance revealed predominance of non-additive gene action for number of fruits / plant and fruit yield/ plant. The obtained values for the variance components showed that the additive component of variance was higher than the dominance component. This clearly suggested that the main part of the genetic variance concerning the mode of inheritance of fruit weight 
belonged to the additive component. The dominant and recessive alleles were not symmetrical in the parents as indicated by the ratio $\mathrm{H}_{2} / 4 \mathrm{H}_{1}$, which was lower than 0.25 . The mean degree of dominance was lower than 1 , indicating the partial dominance controlled the inheritance of fruit weight considering all crossing combinations in the $\mathrm{F}_{1}$ generation (Damnjanovic et al., 2002).

Conclusively, from the foregoing results of this study, it could be concluded that , $\mathrm{t} 2$ for early yield / plant was significant. The estimates of $\mathrm{D}$, $\mathrm{H} \mathrm{1}$, and $\mathrm{H} 2$ were significant for plant height, branch number / plant, early fruit number, fruit weight / fruit in early yield, early yield / plant, total fruit number, fruit weight / fruit in total yield and total yield / plant

\section{REFERENCES}

Abd El-Hadi, A.H., A.M. El-Adl, Z. M. El-Diasty, and E.A. El-Zaghawy (2004). Estimation of heterosis, inbreeding depression and genetic parameters associated with them of some economical traits of eggplant (Solanum melongena L.). Zagazig J. Agric. Res., 31 (5): 2207-2222.

Ahmed, N., M. Hurra, S.A. Wani, and S.H. Khan (2003). Gene action and combining ability for fruit yield and its component characters in sweet pepper. Capsicum and Eggplant Newsletter, 22: 55-58.

Aswani, R.C., and R.C. Khandelwal (2005). Combining ability studies in brinjal. Indian J. Hort,. 62 (1): 37-40.

Baig, K.S., and V.D. Patil (2002). Combining ability over environments for shoot and fruit borer resistance and other quantitative traits in Solanum melongena L. Indian J. Genet., 62 (1): 42-45.

Barbind, L.D. (1990). Heterosis and combining ability studies in brinjal (Solanum melongena L.). for fruit yield, yield components, little leaf, shoot and fruit borer. Unpubl. Ph. D. Thesis, Marathwada Agril. Univ., Parbhani.

Bhutani, R.D., G. Kalloo, G.P. Singh, and A.S. Sidnu (1980). Heterosis and combining ability in brinjal (Solanum melongena L.). Haryana Agric. University J. Res., 10: 476-484.

Bhutani, R.D., G.P. Singh, and G. Kalloo (1977). A note on variability studies in brinjal (Solanum melongena L.). Haryana J. Hort. Sci., 6 (3-4): 190-192. 
Borikar, S.T., V.G. Makne, and U.G. Kulkarni (1981). Note on diallel analysis in brinjal. Indian J. Agric. Sci., 51 (1): 51-52.

Chaudhary, D.R. (1999). Components of genetic variation yield traits of brinjal (Solanum melongena L.). Himachal J. Agric. Res., 25 (1-2): 43-47.

Chezhian, P., S. Babu, and J. Ganeson (2000). Combining ability studies in eggplant (Solanum melongena L.). Tropical Agric. Res., 12: 394397.

Chung, W.B., S.J. Jeong, J.S. Oh, and P.S. Hwang (2003). Genetic analysis of $F_{1}$ generation on eggplant. J. Korean Soc. Hort. Sci., 44 (1): 44-48.

Damnjanovic, J., B. Zecevic, D. Stevanovic, and S. Prodanovic (2002). Inheritance of yield components in diallel crossing of divergent genotypes (Solanum melongena L.). Proceeding $2^{\text {nd }}$ Balkan Symp. Veg. and Potatoes Eds. Acta Hort., 579: 197-201.

Dharme Gowda, M.V. (1977). Genic analysis of yield and yield components in brinjal (Solanum melongena L.). Mysore J. Agric. Sci., 11 (3): 426.

Dharme Gowda, M.V., K.G. Hiremath, and K.V. Goud (1979). Genic analysis of yield and its components in brinjal (Solanum melongena L.). Mysore J. Agric. Sci., 13 (2): 151-155.

Gill, H.S., R.S. Arora, and D.C. Pachauri (1976). Inheritance of quantitative characters in eggplant. Indian J. Agric. Sci., 46(10): 484-490.

Gulam-ud-din, A.S. Arunachilla, and M.I. Tanki.1999. Diallel analysis of some economic traits in eggplant (Solanum melongena L.). Applied Biol. Res., 1(1): 83-84.

Hani, M.B., A.M.. Khalf-Allah, M.M. Abd El-Kader, and M.K. Doos. (1977). Estimation of heterosis in eggplant (Solanum melongena L.). Alex. J. Agric. Res., 25 (3): 465-471.

Hayman, B. I. (1954 a). The theory and analysis of diallel crosses. Genetics, 34: 784-804.

Hayman, B.I. (1954 b). The analysis of variance of diallel table. Biometrics, $10: 235-244$.

Hayman, B.I. (1957). Interaction, heterosis and diallel crosses. Genetics, 42: 336-355. 
Hiremath,K.G., and R.M.R. Gururaja (1974). Genetic variability and correlation studies in Solanum melongena L. Mysore J. Agric. Sci., 8 (2): 197-202.

Iqubal, M.N., M. N. A. Chaudhary, and M.Ch. Sadiq (1995). General and specific combining ability estimates in eggplant (Solanum melongena L.). Capsicum and Eggplant Newsletter, 14: 78-80.

Ismail, H.E. (1997). Diallel analysis in tomato crosses under different environments. M.Sc. Thesis, Fac. Agric. Zagazig Univ. Egypt.

Jinks, J. L. (1954). The analysis of continuous variation in a diallel cross of Nicotiana rustica. Genetics, 39: 767-788.

Jinks, J. L., and B. I. Hayman (1953). The analysis of diallel crosses. Maize Genetics, Newsletter, 27: 48-54.

Kalda, T.S., B.S. Suran, and S.S. Gupta (1988). Phenotypic, genotypic variation and heritable components of some biometrical characters in eggplant. South Indian Hort., 36 (3): 110-113.

Mahaveer, P., M. Nandan, S.N. Dikshit, and S.S. Nichal (2004). Genetic variability, genetic advance and heritability in brinjal (Solanum melongena L.). Orissa J. Hort., 32 (2): 26-29.

Mather, K. and J. L. Jinks (1971). Biometrical Genetics. Dover publication, Inc. New Yourk.

Mehrotar, H.N., and P.K. Dixit (1973). Estimates of variability in eggplant (Solanum melongena L.). Rajasthan J. Agric. Sci., 4 (1): 8-12.

Mital, R.K., S.N. Singh, and H.N. Singh (1976). Genetics of some characters in brinjal (Solanum melongena L.). Veg. Sci., 3 (2): 79-86.

Omkar, S., and J. Kumar. 2005. Variability, heritability and genetic advance in brinjal. Indian J. Hort., 62 (3): 265-267.

Padmanabham, V., and C.A. Jagadish (19960. Combining ability studies on yield potential of round fruited brinjal (Solanum melongena L.). Indian J. Genet., 56 (2): 141-146.

Peter, K.V., and R.D. Singh (1974). Combining ability, heterosis and analysis of phenotypic variation in brinjal. Indian J. Agric. Sci., 44 (6): 393-399.

Salehuzzaman, M., and M.S. Alam (1983). Genetic analysis of yield and its components in the eggplant. SABRAO J., 15 (1): 11-15. 
Singh, A.K., Malhura - Rai, R.S. Pan, V.S. R. K. Prasad and M. Rai. (2002). Combining ability of quantitative characters in brijal (Solanum melongena L.). Vegetable Science, 29 (2):127-130.

Singh, D.P., V.S.R. Krishna Prasad, and R.P. Singh. 1991. Combining ability in eggplant. Indian J. Hort., 48: 52-57.

Singh, S. N., and H. N. Singh. 1979. Heterosis breeding in brinjal. Hort. Sci.,. 7 (1/2): 74-77.

Singh, S. N., and M. H. Hazarika (1982). Note on the relationship between performance per se and general combining ability of parents in eggplant. Indian J. Agric. Sci. , 52: 614-615.

Singh, S.N., H.N. Singh, and M.H. Hazarika (1979). Fractional diallel analysis of some quantitative characters in brinjal. Acta Hort., 93: 307-316.

Vadivel, E., and J.R.K. Bapu (1989). Path analysis of yield components in eggplant. Capsicum Newsletter (8-9): 68-69.

Vijay, O.P., Premnath, and S.H. Jalikop (1978). Combining ability in a diallel cross of brinjal. Indian J. Hort. , 35 (1): 36-38.

Warade, S.D. (1986). Studies on heterosis and combining ability in brijal (Solanum melongena L.). Unpubl. Ph. D. Thesis, Mahatma Phule Agril. Univ., Rahuri. 
المكونات الوراثية لبعض الصفات فى الباذنجان باستخدام تحليل

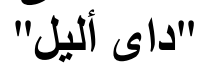

عبد المنعم عامر جـاد ـ المتولي عبد السميع الغمرينى ـ هاني السيا محمد إسماعيل

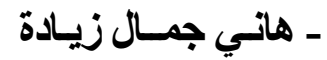
قسم البساتين - كلية الزراعة - جامعة الزقازيق - الزقازيق - مصر.

SBI-1.1 : تم عمل تهجينات بين خمسة آباء من الباذنجان بنظام الداب أليل وهي

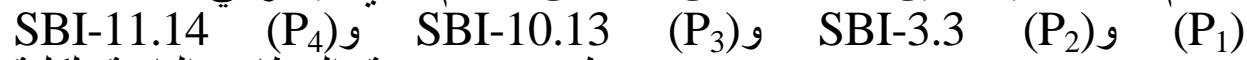

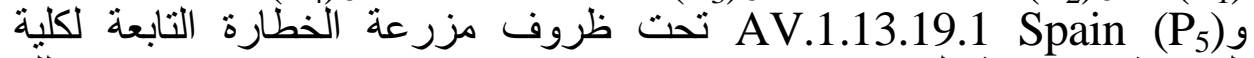

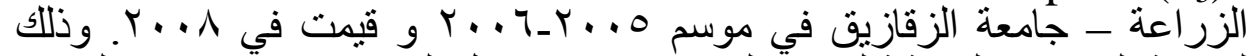

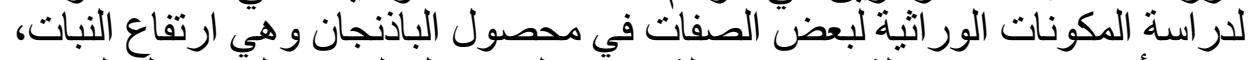

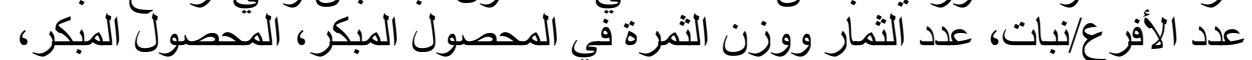

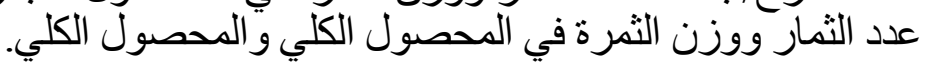

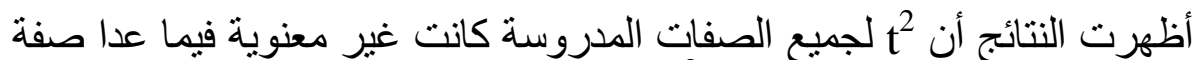

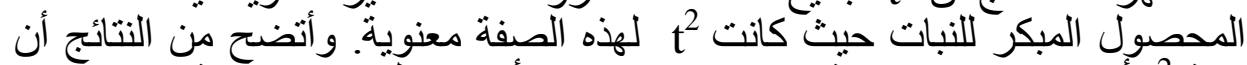

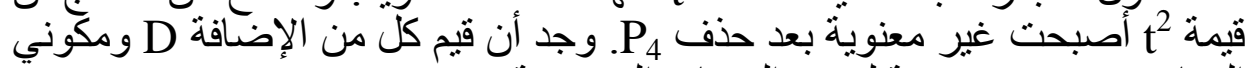
السيادة

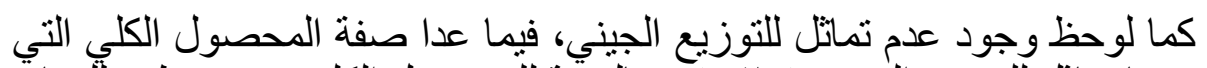

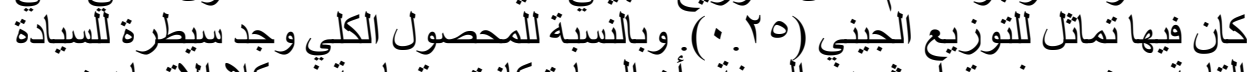

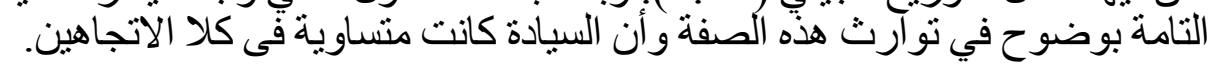

